\title{
Evolutional trends and palaeobiogeography of the Ordovician trilobite Ovalocephalus Koroleva 1959
}

\author{
Zhou Zhiyi $^{1, *}$, Yuan Wenwei ${ }^{1}$ and Zhou Zhiqiang $^{2}$ \\ ${ }^{1}$ Nanjing Institute of Geology and Palaeontology, Chinese Academy of Sciences, \\ Nanjing 210008, People's Republic of China \\ ${ }^{2} X i$ 'an Institute of Geology and Mineral Resources, Xi'an 710054, People's Republic of China
}

\begin{abstract}
Ovalocephalus has a long stratigraphic range and wide geographical distribution in Ordovician peri-Gondwana. Based largely on the well-preserved specimens recently collected from China, all known forms are revised and listed. Phylogenetic analysis was conducted on the genus, involving 10 species. As suggested by the strict consensus tree, evolutional trends of the genus include mainly the isolation of the anterior glabellar portion anterior to S1, the forward shifting of eyes and the related lengthening (exsag.) of the posterior fixigena, the reduction of the number of pygidial axial segments and pleural abaxial rounded free tips, the shortening of the pygidial postaxial region, and the development of cranidial genal spines. Ovalocephalus may have originated in shallow-water sites of the South China Plate in the Early Floian, but migrated into the deep-water regions from the Darriwilian onwards. All the records of the genus from the Early Floian to Early Katian were confined to eastern peri-Gondwanan plates and terranes in low-latitude zones. It was only restricted to the South China, Tarim and North China plates until the Middle Darriwilian, but the Late Darriwilian eustatic sea-level rise and especially the Sandbian-Early Katian immense transgression may have brought about its dispersal to Alborz, Sibumasu and central Asian terranes. Following the closure of the Tornquist Sea, the genus was even able to spread to Baltica during the latest Katian, and the pre-Hirnantian warming (the Boda event) may have promoted a wider distribution of Ovalocephalus to western peri-Gondwana (the Taurides and Armorica terranes) in the thenhigh latitudes.
\end{abstract}

Keywords: Trilobita; Ovalocephalus; Ordovician; evolutional trends; palaeobiogeography

\section{INTRODUCTION}

The Ordovician trilobite genus Ovalocephalus Koroleva 1959 has been considered a senior synonym of Hammatocnemis Kielan 1960 (Dean \& Zhou 1988), Tzuchiatocnemis Sheng $1974 b$ (Zhou \& Dean 1989) and Paratzuchiatocnemis Wu \& Xia 1990 (Zhou \& Zhou $2008 a$ ), and has been recently referred to the subfamily Hammatocneminae in the family Pliomeridae by Yuan et al. (2003). It has a long stratigraphic range and its evolutional trends have been preliminarily depicted by Lu \& Zhou (1979). The genus was capable of migration or dispersion involving distances of thousands of kilometres during periods when eustatic changes of sea level took place, being considered to be of important palaeobiogeographic significance (Lu \& Zhou 1979; Zhou \& Dean 1989). According to the global Ordovician geographical reconstructions proposed by Cocks \& Torsvik (2002) and Fortey \& Cocks (2003), the distribution of the genus covered a wide area from tropic to high-latitude zones, but was largely restricted to peri-Gondwana.

In this paper, the known species of Ovalocephalus are briefly revised, and on this basis the phylogenetic relationships between the species and palaeobiogeographic pattern of the genus are further reviewed. A series of Ordovician global maps provided by Cocks \& Torsvik

*Author for correspondence (zyizhou@jlonline.com).

One contribution to a Special Issue 'Recent advances in Chinese palaeontology'.
(2002) and Fortey \& Cocks (2003) are consulted in the following discussion, and the palaeogeographic or tectonic units employed in the ensuing pages are those of Fortey \& Cocks (2003) and Zhou \& Zhen (2008).

\section{CHRONOSTRATIGRAPHIC, GEOGRAPHICAL AND ENVIRONMENTAL SETTING: A LIST OF SPECIES}

Ovalocephalus was widely spread in the South China, North China and Tarim plates (China), Sibumasu Terrane (westernmost Yunnan and Xainza, central Tibet, China, southern Thailand and northern Burma), Middle Asian terranes (Kazakhstan, Uzbekistan, Kirghizia and Beishan of China), Alborz Terrane (North and Central Iran), Taurides Terrane (southeastern Turkey), Armorica Terrane (northeastern Spain and southern Sardinia, Italy) and Baltica (Poland) during the Ordovician. It was in full flourish especially in the South China Plate, where an almost complete and consistent sequence of various species has been recorded from the Floian to the early Late Katian (Arenig-Early Ashgill), with each species persisting for a quite short time interval. Largely based on the wellpreserved specimens (figure 1) recently collected from the measure sections along bathymetric gradients in the Yangtze area, species of the genus are further revised, in particular those recorded in middle Asia and westernmost Yunnan of China, which were described with no precise stratigraphic age determined. Below are listed all known species of Ovalocephalus, but a few species that were established on the basis of ill-preserved material and their 

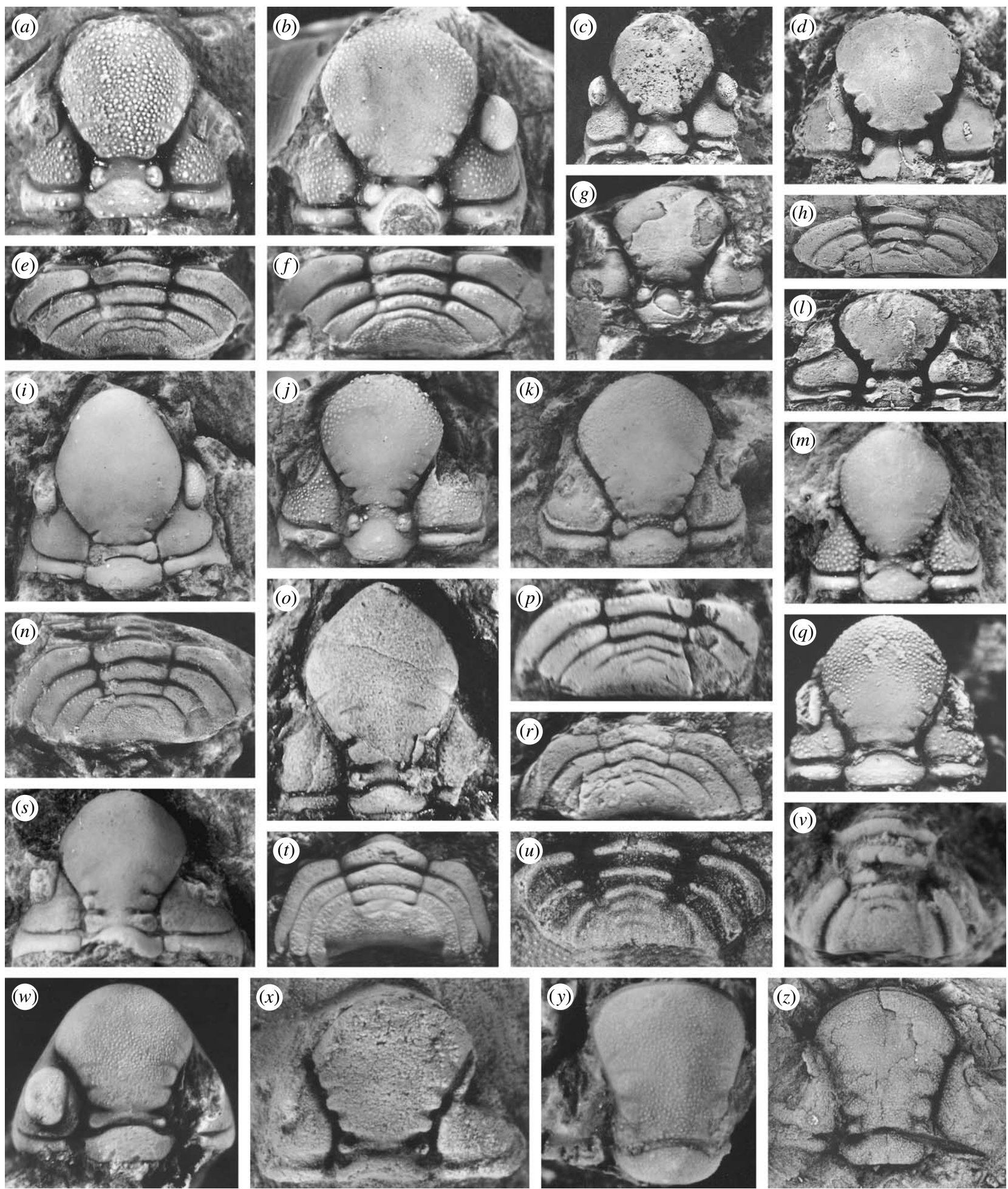

Figure 1. (Caption opposite.)

morphological characters are difficult to interpret, and some fragmentary specimens that show no diagnostic characters are excluded.

\section{(a) Ovalocephalus eoprimitivus Zhou \& Zhou $2008 \mathrm{~b}$ ( figure $1 \mathrm{v}, \mathrm{y}, \mathrm{z}$ )}

This species was recorded from the conodont Oepikodus evae Biozone-Paroistodus originalis Biozone of western Hubei (outer inner shelf; Lu 1975, pl. 45, fig. 6 only, as Hammatocnemis primitious Lu; Turvey \& Zhou 2002, pl. 1, fig. 10 only, as Ovalocephalus primitivus; Zhou \& Zhou $2008 b$ ) and southern Anhui (shallow outer shelf build-ups)
(Yuan et al. 2003, as O. primitivus), South China. It is distributed from the Floian to the Dapingian (Early-Middle Arenig) and characterized by the glabella that gently expands forwards, shows fairly long (tr.) lateral furrows (S2-S4) and lacks the basal transglabellar furrow, by the rearwardsituated palpebral lobe with its posterior margin opposite to the abaxial end of $\mathrm{S} 1$ or $\mathrm{L} 1$, and by the pygidium that displays five axial rings, five pairs of pleurae and a long postaxial region (an incorporated rectangular area of the axial terminal piece and undefined sixth pair of pleurae), which occupies approximately 35 per cent of the pygidial length. 
Figure 1. (Opposite.) Representative specimens of some Ovalocephalus species recorded in China. Figured specimens are deposited at: Nanjing Institute of Geology and Palaeontology; Chinese Academy of Sciences (NIGP); Yichang Institute of Geology and Mineral Resources, Chinese Academy of Geological Sciences (YIGM); and Xi'an Institute of Geology and Mineral Resources, Chinese Academy of Geological Sciences (XIGM). ( $a-h, l)$ Ovalocephalus tetrasulcatus (Kielan 1960). (a) NIGP 27579, cranidium, $\times 8$, and (e) NIGP 27580, pygidium, $\times 6.8$, the upper Pagoda Formation, Liangshan, Nanzheng, southern Shaanxi (respectively, after Zhou, Z. Q. et al. 2000, pl. 2, figs 16 and 15, as Ovalocephalus ovatus); (b) YIGM OT0098, cranidium, $\times 8$, and $(f)$ YIGM OT0101, pygidium, $\times 9$, the upper Pagoda Formation, Puxiheqiao, Yichang, southwestern Hubei (respectively, after Zhou et al. 2005, pl. 6, figs 3 and 9, as O. yangtzeensis); (c) NIGP 27581, cranidium, $\times 3.6$, and (d) XIGM G174, cranidium (after Li et al. 1975, pl. 22, fig. 3, as Hammatocnemis decorosus), $\times 3$, the Chientsaokou Formation, Yuanba, Nanzheng, southern Shaanxi; (g) XIGM Tr191, cranidium (after Zhou et al. 1982, pl. 70, fig. 20), the Xilinkebo Formation, Beishan, northwestern Gansu; (h) NIGP 27582, pygidium, $\times 4$, the Chientsaokou Formation, Zhuyegou, Hujiaba, Ningqiang, southern Shaanxi; $(l)$ NIGP 27583, cranidium, $\times 3$, the Chientsaokou Formation, Qishuba, Mianxian, southern Shaanxi. (i,n,o) Ovalocephalus yichongqiaoensis (Wu \& Xia 1990). (i) YIGM OT0104, cephalon, $\times 8$, and (n) YIGM OT0106, pygidium, $\times 6.7$, the lowest Pagoda Formation, Puxiheqiao, Yichang, southwestern Hubei (respectively, after Zhou et al. 2005, pl. 6, figs 7 and 17); (o) NIGP 27584, cranidium, $\times 7.2$, the lowest Pagoda Formation, Yichongqiao, Cili, northwestern Hunan. ( $j$ ) Ovalocephalus longicervix (Zhou in Lu et al. 1976), NIGP 27585, cranidium, $\times 7.5$, the lower Pagoda Formation, Damugou, Hujiaba, Ningqiang, southern Shaanxi. $(k, m, p, q)$ Ovalocephalus kanlingensis (Zhang 1981). ( $k$ ) NIGP 150170, cranidium, $\times 10$, the lower Pagoda Formation, Yuandun, Mianxian, southern Shaanxi; (m) YIGM OT0094, cranidium (after Zhou et al. 2005, pl. 6, fig. 14), $\times 12.4$, the lower Pagoda Formation, Huanghuachang, Yichang; ( $p$ ) YIGM OT0096, pygidium (after Zhou et al. 2005, pl. 6, fig. 18), $\times 12$, the lower Pagoda Formation, Puxiheqiao, Yichang, southwestern Hubei; $(q)$ NIGP 150171, cranidium, $\times 8.8$, the lower part of the Tumuxiuke Formation, Bachu, Xinjiang. $(r, s)$ Ovalocephalus globosus Abdullaev 1972. (r) NIGP 80680, pygidium (after Zhou \& Dean 1986, pl. 64, fig. 11, as Hammatocnemis obsoletus), $\times 10$, lower part of Chedao Formation, Chedao, Huanxian, eastern Gansu; $(s)$ NIGP 150172, cranidium, $\times 9$, the Datianba Formation, Maocaopu, Rheshi, Taoyuan, northwestern Hunan. ( $t, w)$ Ovalocephalus extraneus (Lu \& Zhou 1979). ( $t$ ) NIGP 56544, pygidium, $\times 8$, and (w) NIGP 56542, cranidium, $\times 8.2$, the top of the Zuozishan Formation, Laoshidan, Wuhai, southwestern Inner Mongolia (after Lu \& Zhou 1979, pl. 1, figs 12 and 1, respectively, as Hammatocnemis primitivus extraneus). (u, $x$ ). Ovalocephalus primitivus (Lu in Lu \& Chang 1974). (u) NIGP 133782, pygidium (after Turvey \& Zhou 2002, pl. 1, fig. 11), $\times 15$, the uppermost Dawan Formation, Daping, Yichang, southwestern Hubei; $(x)$ NIGP 127552, cranidium (after Chen \& Zhou 2002, pl. 1, fig. 7, as Ovalocephalus cf. intermedius (Lu \& Zhou)), $\times 5.5$, the lower part of the Guniutan Formation, Liangshan, Nanzheng, southern Shaanxi. $(v, y, z)$ Ovalocephalus eoprimitivus Zhou \& Zhou 2008b. (v) YIGM OT0113, pygidium, $\times 10.8$, and ( $y$ ) YIGM OT0115, cranidium, $\times 16.8$, the lowest Dawan Formation, Huanghuachang, Yichang; $(z)$ NIGP 133781, cranidium, $\times 8$, the upper Dawan Formation, Daping, Yichang, southwestern Hubei, respectively, after text-fig. 1d,a,c of Zhou \& Zhou (2008b).

\section{(b) Ovalocephalus primitivus ( $\mathrm{Lu}$ in $\mathrm{Lu}$ \& Chang 1974) ( figure 1u,x)}

This form occurs in South China within the Undulograptus austrodentatus graptolite Biozone, and is mainly associated with strata of shallow-outer-shelf facies in northeastern Guizhou (Yin \& Lee 1978, as H. primitivus), central Hubei (Sun 1984, as H. primitivus) and western Hubei (Lu \& Chang 1974; Lu 1975, exclusive of pl. 45, fig. 6; Zhou et al. 1977; Sun 1984; all as H. primitivus; Turvey \& Zhou 2002, pl. 1, fig. 11 only), except for northwestern Hunan, where it has a deep outer shelf setting (Turvey \& Zhou 2004). Recently, it was further found from the Yangtzeplacognatus crassus conodont Biozone in northwestern Hunan in association with an inner deep outer shelf biofacies (Zhou et al. 2001, as O. intermedius Lu \& Zhou), and from the lower Guniutan Formation (Middle Darriwilian or Early Llanvirn; shallow outer shelf; Chen \& Zhou 2002, as O. cf. intermedius) of southern Shaanxi. Outside South China, it was reported from the basal part of the Lenodus variabilis conodont Biozone in the Kalpin area (upper slope) of Tarim, Xinjiang (Zhang 1981, as H. primitivus; Zhou et al. 1998, as O. primitivus extraneus), and from the Pseudamplexograptus confertus graptolite Biozone ( $\mathrm{Lu} \&$ Zhou 1979, as Hammatocnemis intermedius) in southwestern Inner Mongolia (upper slope of the North China Platform; see Zhou et al. 1989). The species is of Early-Middle Darriwilian (Late Arenig-Early Llanvirn) age, and differs from O. eoprimitivus Zhou \& Zhou in the development of a basal transglabellar furrow (although becoming much shallower adaxially), the more forwardly expanded glabellar portion anterior to $S 1$ with shorter (tr.) lateral glabellar furrows, the slightly forward-placed palpebral lobe with its posterior margin in line with L2 or the abaxial end of S2 instead of S1, the correspondingly longer posterior fixigenal area, and the pygidium showing four rather than five pairs of pleurae with the undefined fifth pair merging the axial terminal piece into a trapezoid instead of rectangular pygidial postaxial region that occupies approximately one-quarter rather than 35 per cent of the pygidial length.

\section{(c) Ovalocephalus extraneus (Lu E Zhou 1979) ( figure 1t,w)}

This species was established as $H$. primitivus extraneus by $\mathrm{Lu} \&$ Zhou (1979) from the Lenodus antivariabilis conodont Biozone (Early Darriwilian or Late Arenig) of the western marginal area (upper slope of the North China Platform; see Zhou et al. 1989) in southwestern Inner Mongolia. It agrees well with $O$. eoprimitivus in the rearward-placed palpebral lobe and the comparatively long (tr.) lateral glabellar furrows, but otherwise it is indistinguishable from $O$. primitivus.

\section{(d) Ovalocephalus globosus Abdullaev 1972 ( figure 1r,s)}

This species was first described from the Ordovician of the Bukantau Mountains, Uzbekistan (Abdullaev 1972). After a critical comparison, several Chinese species are considered as its junior subjective synonyms, including Tzuchiatocnemis tzuchiaensis Sheng $1974 b$ from westernmost Yunnan, Hammatocnemis obsoletus Zhou \& Dean 1986 from the Nemagraptus gracilis graptolite Biozone of eastern Gansu (upper slope of the North China Platform; see Zhou et al. 1989), and Paratzuchiatocnemis dialox Wu \& Xia 1990 from the conodont Yangtzeplacognatus protoramosus Biozone and Yangtzeplacognatus jianyeensis-Pygodus anserinus Biozone of northwestern Hunan (shallow outer shelf; see Zhou et al. 2001, as Ovalocephalus obsoletus). This form probably 
ranges from the Late Darriwilian to Early Sandbian (Late Llanvirn-earliest Caradoc), and is closely allied to $O$. extraneus in many respects. The distinct features are the development of a more strongly forwardly expanded anterior glabellar portion in front of the abaxial end of S2 with S3 and S4 more faintly defined, the slightly forwardplaced palpebral lobe with its posterior margin in line with L2, the presence of the genal spine, and the four- rather than five-segmented pygidial axis.

\section{(e) Ovalocephalus kelleri Koroleva 1959 and allies ( figure 1i,n,o)}

There are three closely related species recorded from the Late Sandbian (Early Caradoc). One is the type species O. kelleri Koroleva 1959 (holotype cranidium refigured by Fortey 1997, pl. 9, fig. 7; see also Apollonov 1974) from northern Kazakhstan. It was also reported by Abdullaev in Abdullaev \& Khaletskaya (1970, as Hammatocnemis tetrasulcata Kielan), from Chatkal'skiy Range, Uzbekistan; by Abdullaev (1972, as $H$. globosus), from Bukantau, Uzbekistan; by Repina et al. (1975), from Madygena, Kyrgyzstan; and by Zhou \& Dean (1986), from the lower part of the Sinoceras chinense cephalopod Biozone of eastern Gansu (upper slope of the North China Platform, see Zhou et al. 1989). The second is Ovalocephalus yichongqiaoensis (Wu \& Xia), described from the lower part of the Hamarodus europaeus conodont Biozone (roughly equivalent to the Climacograptus wilsoni graptolite Biozone) by Wu \& Xia (1990, as Paratzuchiatocnemis yichongqiaoensis) and $\mathrm{Ji}$ (1987, as Hammatocnemis ovatus Sheng) in northwestern Hunan (inner deep outer shelf), and documented by Zhou et al. (2005) from the same horizon in northwestern Hubei (shallow outer shelf; see Zhou et al. 1999; Zhou, Z. Y. et al. 2000), South China. The third is Ovalocephalus plewesae Fortey 1997, erected from the lower part of the Pa Kae Formation, southern Thailand. All of them are closely compared with O. globosus, but the cranidium differs in having an elongate, oval to subrhombic anterior glabellar portion with S3 detached from the axial furrow, a basal transglabellar furrow that is deeply incised throughout and a more forwardly situated palpebral lobe with its posterior margin in line with L3. Differences between these forms are tiny. Ovalocephalus plewesae agrees well with $O$. yichongqiaoensis (figure $1 i, n, o$ ), except for the more forwardly pointed glabella. According to Fortey (1997, p. 436), O. kelleri differs from the Thailand form in the less pointed frontal glabellar lobe, the granulose rather than smooth cranidium surface and the more inflated L1.

\section{(f) Ovalocephalus kanlingensis (Zhang 1981) ( figure 1k,m,p,q)}

The species was named as Hammatocnemis kanlingensis by Zhang (1981) from the Corynoides americanus graptolite Biozone (equivalent roughly to the lower part of the Dicranograptus clingani graptolite Biozone) in the Kalpin area and reported from the Lituites cephalopod Biozone or the conodont Pygodus serra Zone-Baltoniodus variabilis Biozone in the Bachu area (upper slope; figure 1q; see Zhou et al. 1992) of Tarim, Xinjiang. It has recently been discovered from South China (figure $1 k, m, p$ ) in the middle part of the $H$. europaeus conodont Biozone (roughly equivalent to the graptolite $D$. clingani Biozone) of northwestern Hubei (shallow outer shelf; Zhou et al. 2005) and northwestern Hunan (inner deep outer shelf; see Zhou et al. 1999; Zhou, Z. Y. et al. 2000), from southern Shaanxi (outer deep outer shelf; see Zhou, Z. Q. et al. 2000), and from Central Iran in the latest Darriwilian (Ghobadi Pour $\&$ Popov 2009, fig. $2 f-h$, as O. aff. obsoletus Zhou \& Dean). In eastern Gansu (then upper slope of the North China Platform; see Zhou et al. 1989), it was recorded from the $N$. gracilis graptolite Biozone by Zhou \& Dean (1986). As suggested by Zhou \& Dean (1986), some specimens described as Hammatocnemis tetrasulcatus Kielan from Tarim, southern Xinjiang (Lu \& Zhou 1979), Madygena, Kyrgyzstan (Repina et al. 1975, pl. 46, figs 1-3, 6-8, 12, 14, non 9-11, 13) and northern Kazakhstan (Apollonov 1974, pl. 13, figs 1 and 3 only) are indistinguishable from, and may therefore be reassigned to, O. kanlingensis. In addition, it may also have a distribution in westernmost Yunnan as suggested by a cranidium reported as $H$. tetrasulcatus by Sheng (1974b, pl. 9, fig. $4 a$ only). This form ranges from the Late Darriwilian to the earliest Katian (Late Llanvirn-early Middle Caradoc). Its anterior glabellar portion is elongate, as long as approximately three-quarters of the glabellar length, as in O. primitivus, but is more inflated, oval in form with the widest width across its mid-length, and better defined by a deep thorough basal transglabellar furrow in the rear. Furthermore, other characters distinct from $O$. primitivus include the development of a pair of genal spines, the more forwardly situated palpebral lobe with its posterior margin in line with L3 and the four- rather than five-segmented pygidial axis.

\section{(g) Ovalocephalus tetrasulcatus (Kielan 1960) and allies (figure 1a-h, j,1)}

Ovalocephalus tetrasulcatus was established as $H$. tetrasulcatus from the latest Katian (Middle Ashgill) of the Holy Cross Mountains, Poland by Kielan (1960). Since then it has successively been described as from the Early Katian (Middle Caradoc) of Chongqing (Sheng \& Ji 1986); the early Late Katian (Early Ashgill) of the Zap Valley, southeastern Turkey (Dean \& Zhou 1988), Chongqing, northeastern Guizhou and northern Sichuan (Sheng 1964), western Zhejiang (Sheng 1974a; Qiu et al. 1983), Beishan, Gansu (Lu \& Zhou 1979 as H. cf. globosus Abdulaev; Zhou et al. 1982; see figure $1 \mathrm{~g}$ ), and westernmost Yunnan (Sheng $1974 b$, pl. 9, fig. $4 b$ only); and the latest Katian (Middle Ashgill) of Aragón, northeastern Spain (Hamman 1992, as Ovalocephalus cf. tetrasulcatus) and southern Sardinia, Italy (Leone et al. 1991; Hamman \& Leone 2007, as O. cf. tetrasulcatus). The species was also recorded from Ulugtau (Repina et al. 1975, pl. 43, figs 17-18, as Hammatocnemis globosus Abdullaev) and Madygena (Repina et al. 1975, pl. 46, figs 9-11, 13 only), Kyrgyzstan and northern Kazakhstan (Apollonov 1974, pl. 13, figs 2, 4-8, non 1, 3). Moreover, a few specimens (e.g. figure $1 l$ ) recently collected from an early Late Katian (Early Ashgill) horizon at Qishuba, southern Shaanxi are likewise typical of this foreign species.

Ovalocephalus longicervix (Zhou in Lu et al. 1976) has a restricted distribution in the deep sites of the outer shelf of the Yangtze sea in northwestern Jiangxi (Zhou in Lu et al. 1976; Lu \& Zhou 1979; Qiu et al. 1983), western Zhejiang (Qiu et al. 1983, including also a cephalon (pl. 82, fig. 3) that was assigned to $H$. ovatus Sheng) and the northern part of southern Shaanxi (figure $1 j$ ). 
It ranges from the upper part of the $H$. europaeus conodont Biozone to the Nankinolithus trilobite Biozone (late Earlyearly Late Katian or late Middle Caradoc-Early Ashgill), being closely allied to $O$. kanlingensis in many respects, especially in having an elongate-oval anterior glabellar portion, but distinct in the more elongate occipital ring, the anterior glabellar portion more adaxially constricted at its base and the more depressed median part of the preoccipital lobe. The last two features in turn render the species quite similar to O. tetrasulcatus.

In addition to longicervix and tetrasulcatus, there were also several additional species of Ovalocephalus being widely documented from the Katian outer shelf facies beds (see Zhou et al. 1999; Zhou, Z. Q. et al. 2000; Zhou, Z. Y. et al. 2000; Zhou et al. 2003) in the Yangtze area. Ovalocephalus ovatus was erected as $H$. tetrasulcatus var. ovatus by Sheng (1964) from the conodont upper $H$. europaeus Biozone-Protopanderodus insculptus Biozone (correlated approximately to the graptolite Diplacathograptus spiniferus Biozone-lower Dicellograptus johnstuptiOrthograptus quadrimucronatus Biozone; late Early Katian or late Middle-Late Caradoc) on the basis of cranidia collected at Nanzheng, southern Shaanxi and Yinjiang, northeastern Guizhou. It was subsequently reported from the upper part of the $H$. europaeus conodont BiozoneNankinolithus trilobite Biozone (late Early-early Late Katian or late Middle Caradoc-Early Ashgill) in Hubei (Lu \& Chang 1974; Lu 1975; Xia 1978; Sun 1984), Chongqing (Lee 1978; Ji 1986; Xiang \& Ji 1986), central Sichuan (Lu 1975), western Hunan (Xiang \& Ji 1988), southern Jiangsu (Tripp et al. 1989), southern Shaanxi (Zhou, Z. Q. et al. 2000) and at other localities of Guizhou (Xiang \& Ji 1988; Yin et al. 2000). Outside South China Plate, O. ovatus occurs in the $\mathrm{Pa}$ Kae Formation of southern Thailand (Fortey 1997).

Other forms successively established and described include Hammatocnemis decorosus $\mathrm{Lu}$ in Lu \& Chang 1974 (Li et al. 1975; Lu 1975; Lee 1978; Xia 1978; Lu \& Zhou 1979, 1981; Liu 1982; Qiu et al. 1983; Sun 1984; Tripp et al. 1989; Zhou, Z. Y. et al. 2000); H. hexianensis Zhang in Qiu et al. 1983; H. huayinshanensis Lu in Lu \& Chang 1974 (Lu 1975); H. liangshanensis Chen in Li et al. 1975; H. minor Chen in Li et al. 1975 (Xiang \& Zhou in Wang et al. 1987); H. nanzhengensis Zhou in Li et al. 1975; $H$. orientalis Chen in $\mathrm{Li}$ et al. 1975; H. pogodus Chen in $\mathrm{Li}$ et al. 1975; and H. sinensis Han 1980; H.(?) tudilingensis Chen in $\mathrm{Li}$ et al. 1975; and H. yangtzeensis $\mathrm{Lu}$ in $\mathrm{Lu} \&$ Chang 1974 (Lu 1975; Xia 1978; Sun 1984; Yin et al. 2000; Zhou, Z. Y. et al. 2000; Zhou et al. 2005).

However, after revised by Lu \& Zhou (1979) and Yuan et al. (2003), only two of the listed forms-O. ovatus and O. yangtzeensis - were considered as valid. Recently, Zhou et al. (2005, p. 342) have further suggested that O. ovatus was probably a senior subject synonym of $O$. yangtzeensis. A close comparison between the related specimens we collected from Nanzheng, sorthern Shaanxi (type locality of ovatus) and Yichang, western Hubei (type locality of yangtzeensis) indicates with confidence that both forms are almost identical in all the diagnostic characters (compare figure $1 a, e$ with figure $1 b, f$ ).

On the basis of the holotype cephalon (Kielan 1960, pl. 26, fig. 2), O. tetrasulcatus differs from O. ovatus mainly in the proportionally much shorter (wider than long) and more strongly forwardly expanded anterior glabellar portion, but one well-preserved paratype cranidium (Kielan 1960, pl. 27, fig. 6) agrees well with that of the Chinese form. As noted by Tripp et al. (1989), Fortey (1997) and Hamman \& Leone (2007), some of the superficial differences between the types are preservational, because most of the Polish specimens are external moulds. In this regard, we prefer herein to consider both the species as synonymous.

The young species of Ovalocephalus, O. longicervix and $O$. tetrasulcatus are characterized by the glabella with strongly inflated and basically oval-shaped anterior portion in front of $\mathrm{S} 1$, well isolated and highly convex L1, long and strongly forward-arched occipital ring, and depressed rather than elevated (as in kanlingensis) median part of the preoccipital ring.

\section{EVOLUTIONAL TRENDS}

Ovalocephalus made its earliest appearance in the Floian and was restricted to the shallow-water sites of the South China Plate during the late Early-early Middle Ordovician, then subsequently migrated from the Darriwilian onwards into the deep-water regions. The nearshore origination and offshore development of the genus seems to support the hypothesis (Jablonski et al. 1983) on the macroevolution of marine benthic faunas.

In order to assess the relationships among the 10 species of Ovalocephalus, phylogenetic analysis was conducted using PAUP v. 4.0.b10 (Swofford 2003) on the basis of a dataset of 17 scored characters (see appendix A for details). The result is distilled into figure 2 .

Ovalocephalus eoprimitivus, the oldest known species of the genus, is considered a probable ancestral form. Two subclades (figure 2) arose from it since the Darriwilian. One is represented by a single representative extraneus, and the other includes primitivus, kanlingensis, tetrasulcatus, longicervix, globosus, kelleri, yichongqiaoensis and plewesae. In the latter subclade, two groups of species are well resolved as monophyletic. The first consists of closely related Late Sandbian forms kelleri, yichongqiaoensis and plewesae, although their relationships are still ambiguous according to the strict consensus tree (see appendix A), each of which retains some primitive characters as shown in eoprimitivus and globosus (i.e. the comparatively long (tr.) lateral glabellar furrows, the gently convex L1 and the short occipital ring with anterior margin gently arched forwards). As distinct from the allied earlier form globosus, all of them basically have an elongate-oval instead of oval anterior glabellar portion.

The second group involves kanlingensis, tetrasulcatus and longicervix. All of them show fairly convex L1, almost abaxially extended pleurae in outer portion of pygidial pleura and fairly short (tr) lateral glabellar furrows, the latter of which is suggested as a homoplasic feature (appendix A). The Late Darriwilian-earliest Katian representative kanlingensis is characterized by the ovalshaped, inflated anterior glabellar portion, the rear of which is well defined by an elevated preoccipital ring. In the young forms tetrasulcatus and longicervix, the anterior glabellar portion is further inflated, while the preoccipital ring is turned to be rather depressed for most part but with well isolated and highly convex $\mathrm{L} 1$, and the occipital ring is much lengthened with anterior margin more strongly arched forwards. 


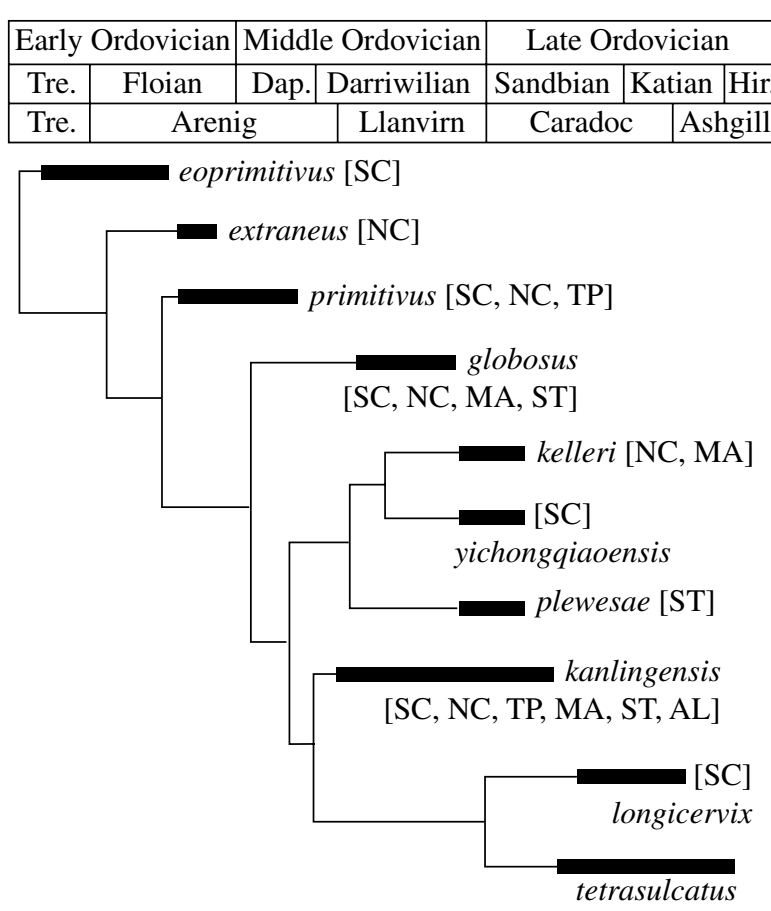

[SC, MA, ST, TT, AT, BP]

Figure 2. Strict consensus cladogram of Ovalocephalus (figure 4, appendix A) plotted against Ordovician chronostratigraphic scheme, showing phylogenetic, stratigraphic and geographical relationships among its species. Thick vertical lines indicate stratigraphic ranges based largely on the data from China. Geographical distribution of each species is listed in square brackets. Tre., Tremadocian; Dap., Dapingian; Hir., Hirnantian; AL, Alborz Terrane; AT, Armorica Terrane; BP, Baltica Plate; MA, Middle Asian terranes; NC, North China Plate; SC, South China Plate; ST, Sibumasu Terrane; TP, Tarim Plate; TT, Taurides Terrane.

It is interesting to note that the sequential speciation suggested from the strict consensus cladogram (appendix A, figure 4) seems synchronous with the stratigraphic succession (figure 2). In general, the evolutional trends exhibited in the whole clade include the development of the basal transglabellar furrow (since the Early Darriwilian); the deepening of the basal transglabellar furrow and the isolation of the anterior glabellar portion (since the Late Darriwilian in the kanlingensis species group, but taking place in the Late Sabadian in the kelleri species group); the forward shifting of eyes (with their posterior margin in line with S1 in O. extraneus, with L2 or the abaxial end of S2 in primitivus, with L2 in globosus, and with L3 in all other species) and, correspondingly, the lengthening (exsag.) of the posterior fixigena; the reduction of the number of pygidial axial segments from five (in primitivus and extraneus) to four (in all younger species); the reduction of the number of abaxial rounded free tips of pygidial pleurae from three (in primitivus, extraneus and globosus) to one (in all younger species); and the progressively shortening of the pygidial postaxial region (since the Early Darriwilian). In addition, pleurae in the outer portion of pygidial pleura are almost backwardly extended in older species (primitivus and extraneus), but become postero-laterally extended in all the species in the kelleri group, or almost abaxially extended in species of the kanlingensis group. Moreover, in contrast with the older, all the younger (Late Darriwilian-Katian) species of the genus bear a pair of cranidial genal spines.
As revealed by Yuan et al. (2003), ontogenetic changes of the earliest known species $O$. eoprimitivus include the widening of the posterior part of the preoccipital glabella; posterior shift of the palpebral lobe and related shortening of the posterior fixigenal field; progressive reduction and finally degeneration of the fixigenal spine; and reduction in the number of pygidial pleurae and axial rings. The adults of the species from the Floian to Late Katian successively exhibit more immature features, suggesting that paedomorphosis plays an important role in the evolution of the genus.

\section{PALAEOBIOGEOGRAPHIC IMPLICATIONS}

Judging from the morphological features, Ovalocephalus is a typical benthic form, but the ontogenetic series of $O$. eoprimitivus does indicate that the genus has a single non-adult-like planktonic anaprotaspid larval stage (Yuan et al. 2003, text-fig. 3a,b), suggesting a life-history strategy II of Chatterton \& Speyer (1997). The wide distribution of Ovalocephalus may, therefore, be a result of its effective larval dispersal. As suggested by Zhou \& Dean (1989) and Cocks \& Fortey (1990), there is no evidence for the presence of oceanographic barriers that might have prevented migration and dispersal of trilobites between different geographical units of Ordovician Gondwana and peri-Gondwana.

Except for O. eoprimitivus, almost all other species from Darriwilian to Katian are associated with outer shelf/slope environments. Despite being a basically deep-water trilobite genus, Ovalocephalus shows a relatively restricted palaeogeographic distribution during the Floian-Early Katian. All the records of the genus from these time intervals were confined to eastern peri-Gondwana plates and terranes in low-latitude zones.

It appears that Ovalocephalus may have originated in the South China Plate during the Early Floian following the Tremadocian/Early Arenig (Floian) regressivetransgressive couplet (Fortey 1984), which accompanied the development of endemic trilobite faunas as noted by Zhou \& Fortey (1986). The dispersion of the genus to other parts of the eastern peri-Gondwana areas seems largely to have been induced directly by the global transgressive events. Ovalocephalus was restricted only to a few localities in the South China Plate until the Dapingian. However, the Early Darriwilian transgression (e.g. Nielsen 1992; $\mathrm{Su}$ 2001) may have caused scattering in the Yangtze region and intercontinental dispersal of the genus to the Tarim and North China plates. Following a short-period regressive phase occurring between the Middle and Late Darriwilian, a eustatic sea-level rise (e.g. Su 2001; Nielsen 2004) during the Late Darriwilian may have brought about the further dispersal of Ovalocephalus to Sibumasu, Alborz and central Asian terranes. The Caradoc (Sandbian-Early Katian) was a period when the Ordovician climax transgression took place (Fortey 1984; Zhou et al. 1989, 1992; Barnes 2004). This event may have led to the development of new ecological associations along a range of new environmental niches and, as a result, the increase in species diversity of Ovalocephalus in these low-latitude regions may have been especially early at this stage.

Whittington \& Hughes (1972) indicated that the trilobite faunas had progressively decreased in provinciality from the Floian or Arenig onwards during the 


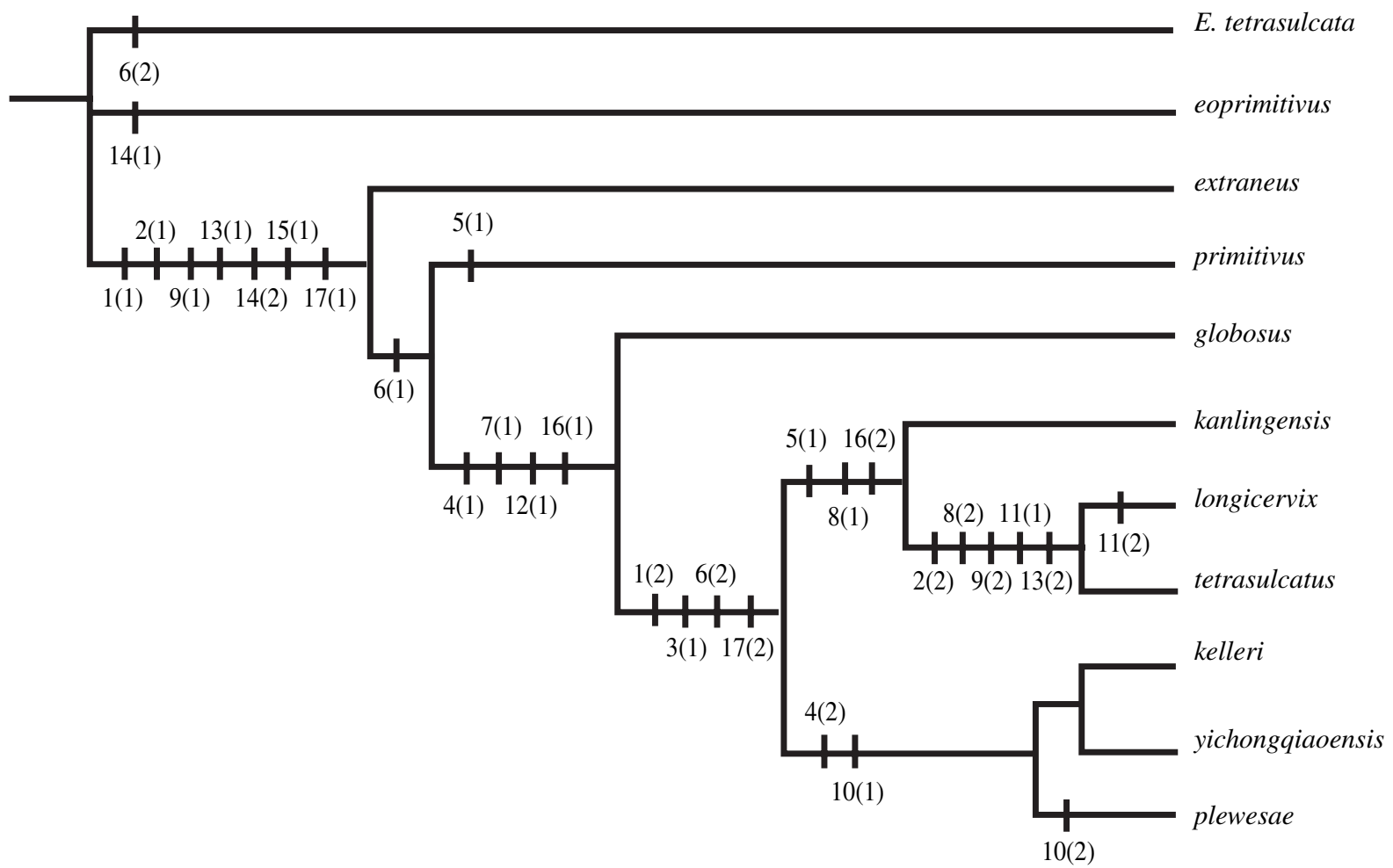

Figure 3. Cladogram showing one most parsimonious tree with length 31, CI of 0.9355 and RI of 0.9500.

Ordovician. Recently, Fortey \& Cocks (2003) have provided further evidence for the Late Katian or Ashgill breakdown of faunal provincialism. Although the Late Katian may represent a stage of lowstand interval in terms of eustatic sea levels (Nielsen 2004), the proposed brief pre-Hirnantian warming or the Boda event (Fortey \& Cocks 2005) may have resulted in a poleward invasion, dispersal or migration of the benthic faunas, and promoted a wider distribution of Ovalocephalus to western peri-Gondwana (the Taurides and Amorica terranes) in the then-high latitudes prior to its final demise during or before the first episode of the end Ordovician mass extinction event. The latest Katian or Middle Ashgill saw also the spread of the genus onto the Holy Cross Mountain of Poland, a part of Baltica then situated in the low-latitude zones (Cocks \& Torsvik 2002; Fortey \& Cocks 2003), following the closure of the Tornquist Sea. However, Ovalocephalus almost died out in eastern peri-Gondwanan plates and terranes during most of the Late Katian (late Early-Middle Ashgill) due to either the unsuitable living environments (e.g. the wide distribution of graptolite facies beds in the South China Plate and Sibumasu Terrane, of littoral clastics in the Tarim Plate, and of the graptolite facies deposits, carbonate build-ups and inner shelf clastics in the Middle Asian terranes), or the omission of coeval rocks (North China Plate).

The research was supported by the Ministry of Science and Technology of China (2006CB806402), the National Natural Science Foundation of China (40532009, 40772007), the Chinese Academy of Sciences (KZCX2-YW-Q05-01) and the State Key Laboratory of Palaeobiology and Stratigraphy (20081103). We are greatly obliged to two anonymous reviewers for their constructive comments.

\section{APPENDIX A}

In order to assess the relationships among the 10 species of Ovalocephalus, cladistic analysis was conducted.

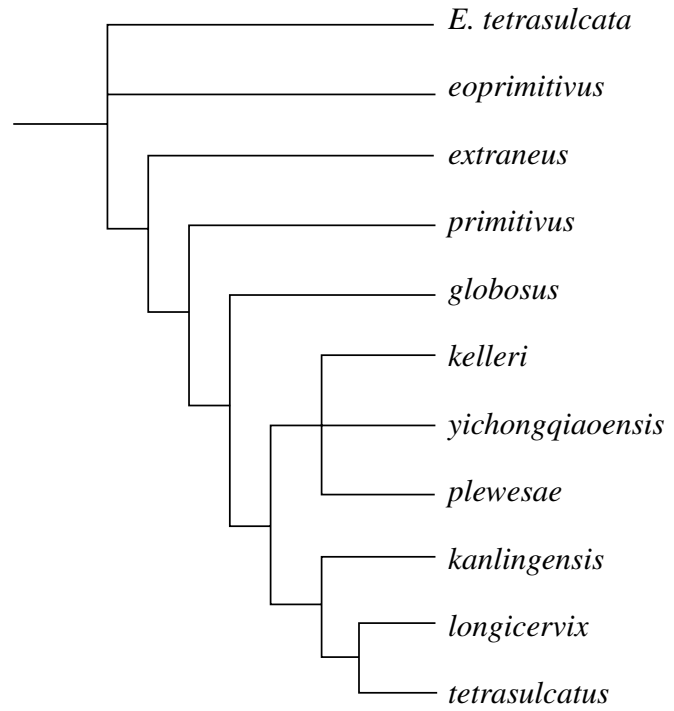

Figure 4. Cladogram showing strict consensus tree of two most parsimonious cladograms.

\section{(a) Characters and character states}

An investigation of adult morphology was carried out for the phylogenetic analysis, in which 17 cranidial and pygidial characters were scored across the ingroup and outgroup species. As hypostomes have not been found in most species and librigenae usually have no diagnostic characters, characters of them are therefore not employed in the analysis. Although type material was studied where possible, the characters available for analysis were often defined on the basis of well-preserved specimens for most species. Some characters proved to be preservational, which were excluded from the dataset. Encrinuella is selected as outgroup taxon as it is closely allied to Ovalocephalus. It was coded using E. tetrasulcata $\mathrm{Ju}$ in $\mathrm{Lu} \&$ Zhou 1981 (see also Tripp et al. 1989, 
fig. $14 b, g, h, m)$ rather than its type species $E$. inshangensis (Reed), as the Chinese form is more completely preserved and the type specimens are more easy to access.

The characters and their states are listed below, of which 6 are binary and 11 are multistates.

(i) Basal transglabellar furrow: 0, absent; 1, present but shallow mesially; 2 , present but deep throughout.

(ii) Median part of preoccipital ring: 0, absent; 1 , present and gently elevated; 2 , present and depressed.

(iii) Isolation of anterior part of glabella anterior to $\mathrm{S} 1$ : 0 , not isolated from the rear glabellar portion; 1 , isolated from the rear glabellar portion.

(iv) Shape of anterior part of glabella anterior to $\mathrm{S} 1$ : 0 , axe shaped; 1 , oval; 2 , elongate oval.

(v) Lateral glabellar furrows: 0, long (tr.); 1 , short (tr.).

(vi) Posterior margin of palpebral lobe: 0, in line with abaxial end of $\mathrm{S} 1$ or $\mathrm{L} 1 ; 1$, in line with $\mathrm{L} 2$ or abaxial end of S2; 2, in line with abaxial end of L3.

(vii) Fixigenal spine: 0, absent; 1, present.

(viii) L1: 0, gently convex; 1, fairly convex; 2, well isolated and highly convex.

(ix) Convexity of anterior part of glabella anterior to S1: 0, gently convex and not overhanging anterior cranidial border; 1, convex and slightly overhanging anterior cranidial border; 2, strongly convex and overhanging anterior cranidial border.

(x) Anterior margin of glabella: 0, broadly rounded; 1 , narrowly rounded; 2 , pointed.

(xi) Occipital ring: 0 , short (less than one-third as long as wide) with anterior margin gently arched forwards; 1, long (less than half as long as wide) with anterior margin prominently arched forwards; 2, very long (more than two-thirds as long as wide) with anterior margin strongly arched forwards.

(xii) Number of pygidial axial rings: 0, 5; 1, 4.

(xiii) Sagittal pygidial length posterior to fourth axial ring: 0 , around 40 per cent of pygidial length; 1 , around 30 per cent of pygidial length; 2 , around 25 per cent of pygidial length.

(xiv) Pygidial postaxial region (an incorporated area of the axial terminal piece and posterior undefined pleurae): 0 , absent; 1 , present and rectangular in shape; 2, present and trapezoid in shape.

(xv) Number of pygidial pleurae: 0,$5 ; 1,4$.

(xvi) Pleurae in outer portion of pygidial pleura: 0 , almost backwardly extended; 1 , postero-laterally extended; 2, almost abaxially extended.

(xvii) Number of abaxial rounded free tips of pygidial pleurae: 0,$5 ; 1,3 ; 2,1$.

\section{(b) Results of the cladistic analysis}

The data matrix for all the ingroup and outgroup species is presented in table 1. All characters were treated as unordered and unweighted. Parsimony analysis was conducted on PAUP v. 4.0.b10 (Swofford 2003), employing the exact branch and band algorithm and accelerated transformation optimization (ACCTRAN). Within these parameters, two equally parsimonious cladograms of

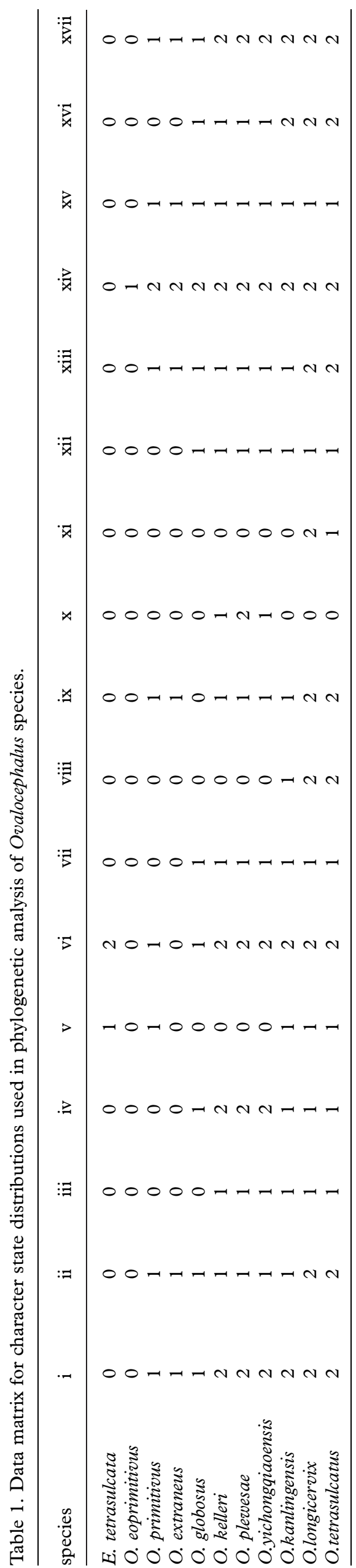


length 31, consistency index (CI) 0.9355 and retention index (RI) 0.9500 were found. One of the shortest trees and the strict consensus tree are shown in figures 3 and 4 , respectively.

\section{REFERENCES}

Abdullaev, R. N. 1972 Trilobites of the Upper Ordoviian of Bukantau. In New data on the fauna of the Palaeozoic and Mesozoic of Uzbekistan (eds A. S. Masymov \& R. N. Abdullaev), pp. 103-126. Tashkent, Uzbekistan: Akdemiya NAUK Uzbekskoy SSR Instituta Geologii I Geofiziki.

Abdullaev, R. N. \& Khaletskaya, O. N. 1970 Lower Paleozoic of the Chatkalskiy Range: trilobites and graptolites of the Ordovician of the Pskemskiy Range. Tashkent, Uzbekistan: Institut Geologii i Geofiziki.

Apollonov, M. K. 1974 Ashgill trilobites from Kazakhstan. Almaty, Kazakhstan: Akademiya Nauk Kazakh SSR.

Barnes, C. R. 2004 Ordovician oceans and climate. In The great Ordovician biodiversification event (eds B. D. Webby, F. Paris, M. L. Droser \& I. G. Percival), pp. 72-76. New York, NY: Columbia University Press.

Chatterton, B. D. E. \& Speyer, S. E. 1997 Ontogeny. In Treatise on invertebrate paleontology. Part O: Arthropoda 1, Trilobita, revised, vol. 1 (ed. R. L. Kaesler), pp. 173-247. Boulder, CO; Lawrence, KS: Geological Society of America and University of Kansas.

Chen, R. Y. \& Zhou, Z. Y. 2002 An Ordovician (early Llanvirn) trilobite faunule from Nanzheng, southern Shaanxi. Acta Palaeontol. Sin. 41, 219-231.

Cocks, L. R. M. \& Fortey, R. A. 1990 Biogeography of Ordovician and Silurian faunas. Geol. Soc. Lond. Memoir 12, 97-104. (doi:10.1144/GSL.MEM.1990.012.01.08)

Cocks, L. R. M. \& Torsvik, T. H. 2002 Earth geography from 500 to 400 million years ago: a faunal and palaeomagnetic review. F. Geol. Soc. Lond. 159, 631-644. (doi:10.1144/ 0016-764901-118)

Dean, W. T. \& Zhou, Z. Y. 1988 Upper Ordovician trilobites from the Zap Valley, south-east Turkey. Palaeontology 31, 621-649.

Fortey, R. A. 1984 Global early Ordovician transgression and regression and their biological implications. In Aspects of the Ordovician system (ed. D. L. Bruton), pp. 37-50. Oslo, Norway: Universitetsforlaget.

Fortey, R. A. 1997 Late Ordovician trilobites from southern Thailand. Palaeontology 40, 397-449.

Fortey, R. A. \& Cocks, L. R. M. 2003 Palaeontological evidence bearing on global Ordovician-Silurian continental reconstructions. Earth-Sci. Rev. 61, 245-307. (doi:10. 1016/S0012-8252(02)00115-0)

Fortey, R. A. \& Cocks, L. R. M. 2005 Late Ordovician global warming - the Boda event. Geology 33, 405-408. (doi:10. 1130/G21180.1)

Ghobadi Pour, M. \& Popov, L. E. 2009 First report on occurrence of Neseuretinus and Ovalocephalus trilobites in the Middle Ordovician of Iran. Acta Palaeontol. Pol. 54, 125-133.

Hamman, W. 1992 The Ordivican trilobites from the Iberian Chains on the province of Aragón, NE Spain. 1. The trilobites of the Cystoid Limestone (Ashgill Series). Beringeria 6, 1-219.

Hamman, W. \& Leone, F. 2007 The trilobites from the 'postSardic' (Upper Ordovician) sequence of the Iglesiente, Arburese and Sarrabus region, southern Sardinia, Italy. Part 2. Beringeria 38, 1-138.

Han, N. R. 1980 On the exoskeleton of Hammatocnemis Kielan, 1959 (Trilobita). Geol. Rev. 26, 183-189.
Jablonski, D., Sepkoski Jr, J. J., Bottjer, D. J. \& Sheeran, P. M. 1983 Onshore-offshore patterns in the evolution of Phanerozoic shelf communities. Science 222, 1123-1125. (doi:10.1126/science.222.4628.1123)

Ji, Z. L. 1986 Upper Ordovician (middle Caradoc-early Ashgill) trilobites from the Pagoda Formation in South China. Prof. Papers Stratigr. Palaeontol. 15, 1-33.

Ji, Z. L. 1987 Some Middle and Upper Ordovician trilobites from western Hunan. Prof. Pap. Stratigr. Palaeontol. 17, 247-256.

Kielan, Z. 1960 Upper Ordovician trilobites from Poland and some related forms from Bohemia and Scandinavia. Palaeontol. Pol. 11, 1-198.

Koroleva, M. N. 1959 New genera of trilobites from the Middle and Upper Ordovician of northern Kazakhstan. Doklady Akademia Nauk SSR 124, 1313-1316.

Lee, S. J. 1978 Trilobita. In Palaeontological atlas of southwest China, Sichuan volume, Part 1, Sinian to Devonian, pp. 179-284. Beijing, China: Geological Publishing House.

Leone, F., Hamman, W., Laske, R., Serpagli, E. \& Viillas, E. 1991 Lithostratigraphic units and biostratigraphy of the post-Sardic Ordovician sequence in south-west Sardinia. Bolletino della Società Paleontologica Italiana 30, 201-235.

Li, Y. X., Song, L. S., Zhou, Z. Q. \& Yang, J. Y. 1975 Stratigraphical Gazetteer of Lower Palaeozoic, Western Dabashan. Beijing, China: Geological Publishing House pp. 1-372

Liu, Y. R. 1982 Trilobita. In Palaeontological atlas of Hunan (ed. S. Q. Li). Ministry of Geology and Mineral Resources, Geological Memoirs, Series 2, Stratigraphy and Palaeontology, no. 1, pp. 290-347. Beijing, China: Geological Publishing House.

Lu, Y. H. 1975 Ordovician trilobite faunas of central and southwestern China. Palaeontol. Sin. (New Ser. B) 10, $1-484$.

Lu, Y. H. \& Chang, W. T. 1974 Ordovician trilobites. In Handbook of stratigraphy and palaeontology, southwest China, (ed. Nanjing Institute of Geology and Palaeontology, Academia Sinica), pp. 124-136. Beijing, China: Science Press.

Lu, Y. H. \& Zhou, Z. Y. 1979 Systematic position and phylogeny of Hammatocnemis (Trilobita). Acta Palaeontol. Sin. 18, 415-433.

Lu, Y. H. \& Zhou, Z. Y. 1981 Early Upper Ordovician trilobites from the Nanjing Hills. Bull. Nanjing Inst. Geol. Palaeontol. Acad. Sin. 3, 1-27.

Lu, Y. H., Zhu, Z. L., Qian, Y. Y., Zhou, Z. Y., Chen, J. Y., Liu, G. W., Yu, W., Chen, X. \& Xu, H. K. 1976 Ordovician biostratigraphy and palaeozoogeography of China. Memoirs Nanjing Inst. Geol. Palaeontol. Acad. Sin. 7, 1-83.

Nielsen, A. T. 1992 International correlation of the Arenig (Early Ordovician) based on sequence and ecostratigraphy. In Global perspectives on Ordovician geology (eds B. D. Webby \& J. R. Laurie), pp. 367-379. Rotterdam, The Netherlands: A.A. Balkema.

Nielsen, A. T. 2004 Ordovician sea level changes: a Baltoscandian perspective. In The great Ordovician biodiversification event (eds B. D. Webby, F. Paris, M. L. Droser \& I. G. Percival), pp. 84-93. New York, NY: Columbia University Press.

Qiu, H. A. et al. 1983 Trilobita. In Palaeontological atlas of east China (1), pp. 28-254. Beijing, China: Geological Publishing House.

Repina, L. N., Petrunina, Z. E. \& Hajrullina, T. I. 1975 Trilobites. In Stratigraphy and fauna of the Lower Palaeozoic of the Northern Submontain Belt of Turkestan and Alai Ridges (Southern Tyan-shan). Akademiya Nauk SSSR, Sibirskoe Otdelenie, Institut Geologii i Geofiziki, Trudy, 278, 100-248. 
Sheng, X. F. 1964 Upper Ordovician trilobite faunas of Szechuan-Kaeichow with special discussion on the classification and boundaries of the Upper Ordovician. Acta Palaeontol. Sin. 12, 537-564.

Sheng, X. F. 1974a On the age of Chinese Dalmanitina beds. In Subdivision and correlation of the Ordovician in China, pp. 53-95. Beijing, China: Geological Publishing House.

Sheng, X. F. $1974 b$ Ordovician trilobites from western Yunnan and its stratigraphical significance. In Subdivision and correlation of the Ordovician in China, pp. 96-140. Beijing, China: Geological Publishing House.

Sheng, X. F. \& Ji, Z. L. 1986 On the age of the Pagoda Formation. Prof. Pap. Stratigr. Palaeontol. 16, 1-36.

$\mathrm{Su}, \mathrm{W} . \mathrm{B} .2001$ Ordovician sequence stratigraphy and sea-level changes in the southeastern marginal areas of the Upper Yangtze platform. Beijing, China: Geological Publishing House.

Sun, Z. H. 1984 Trilobita. In Palaeontological atlas of Hubei Province, pp. 328-422. Wuhan, China: Hubei Science and Technology Press.

Swofford, D. L. 2003 PAUP* phylogenetic analysis using parsimony (* and other methods), Beta v. 4.0.b10. Sunderland, MA: Sinauer Associates.

Tripp, R. P., Zhou, Z. Y. \& Pan, Z. Q. 1989 Trilobites from the Upper Ordovician Tangtou Formation, Jiangsu Province, China. Trans. R. Soc. Edinb. Earth Sci. 80, 25-68.

Turvey, S. T. \& Zhou, Z. Y. 2002 Arenig trilobite associations of Daping, Yichang, Hubei, South China. Acta Palaeontol. Sin. 41, 10-18.

Turvey, S. T. \& Zhou, Z. Y. 2004 Arenig trilobite associations from the Jiangnan Transitional Belt of northwestern Hunan. China. F. Asian Earth Sci. 23, 47-61. (doi:10. 1016/S1367-9120(03)00094-4)

Wang, X. F., Xiang, L. W., Ni, S. Z., Zeng, Q. L., Xu, G. H., Zhou, T. M., Lai, C. G. \& Li, Z. H. 1987 Biostratigraphy of the Yangtze Gorge area (2): Early Palaeozoic era. Beijing, China: Geological Publishing House.

Whittington, H. B. \& Hughes, C. P. 1972 Ordovician geography and faunal provinces deduced from trilobite distribution. Phil. Trans. R. Soc. Lond. B 263, 235-278. (doi:10.1098/rstb.1972.0001)

Wu, J. W. \& Xia, S. F. 1990 A Caradocian new trilobite genus from Cili County, Hunan Province. F. Nanjing Univ. (Nat. Sci. Ed.) 26, 168-172.

Xia, S. F. 1978 Ordovician trilobites. In Sinian to Permian stratigraphy and palaeontology of the eastern Yangtze Gorge area (ed. Stratigraphic Researh Group of Yangtze Gorges, Hubei Bureau of Geology), pp. 157-185. Beijing, China: Geological Publishing House.

Xiang, L. W. \& Ji, Z. L. 1986 Upper Ordovician (Ashgill) trilobites from the Linxiang Formation of western Hunan and eastern Guizhou. Bull. Chin. Acad. Geol. Sci. 12, 53-66.

Xiang, L. W. \& Ji, Z. L. 1988 Upper Ordovician (middle Ashgill) trilobites from the Linxiang formation in southern China. Prof. Pap. Stratigr. Palaeontol. 19, 1-20.

Yin, G. Z. \& Lee, S. J. 1978 Trilobita. In Palaeontological atlas of Southwest China, Guizhou Province (1): CambrianDevonian, pp. 385-595. Beijing, China: Geological Publishing House.

Yin, G. Z., Tripp, R. P., Zhou, Z. Y., Zhou, Z. Q. \& Yuan, W. W. 2000 Trilobites and biofacies of the Ordovician Pagoda Formation, Donggongsi of Zunyi, Guizhou Province, China. Trans. R. Soc. Edinb. Earth Sci. 90, 203-220.

Yuan, W. W., Zhou, Z. Y., Siveter, D. J. \& Zhou, Z. Q. 2003 The ontogeny of the Ordovician trilobite Ovalocephalus and its bearing on the affinity and evolution of the genus. Special Papers Palaeontol. 70, 259-269.
Zhang, T. R. 1981 Trilobita. In Palaeontological atlas of Northwest China, Xinjiang, vol. 1, pp. 134-213. Beijing, China: Geological Publishing House.

Zhou, T. M., Liu, Y. R., Meng, X. S. \& Sun, Z. H. 1977 Trilobites. In Palaeontological atlas of Central and Southern China (1): Early Palaeozoic, pp. 104-266. Beijing, China: Geological Publishing House.

Zhou, Z. Q., Li, J. S. \& Qu, X. G. 1982 Trilobites. In Palaeontological atlas of Northwest China: ShaanxiGansu-Ningxia (1): Precambrian and Early Palaeozoic, pp. 215-294. Beijing, China: Geological Publishing House.

Zhou, Z. Q., Zhou, Z. Y. \& Yuan, W. W. 2000 Middle Caradoc trilobite biofacies of the Micangshan Area, northwestern margin of the Yangtze Block. F. Stratigr. 24, 264-274.

Zhou, Z. Q., Zhou, Z. Y. \& Yuan, W. W. 2005 Late Ordovician trilobite fauna and succession, Yichang, Hubei Province, China. Acta Palaeontol. Sin. 44, 327-357.

Zhou, Z. Y. \& Dean, W. T. 1986 Ordovician trilobites from Chedao, Gansu Province, north-west China. Palaeontology 29, 743-786.

Zhou, Z. Y. \& Dean, W. T. 1989 Trilobite evidence for Gondwanaland in East Asia during the Ordovician. 7. Southeast Asian Earth Sci. 3, 131-140. (doi:10.1016/ 0743-9547(89)90017-2)

Zhou, Z. Y. \& Fortey, R. A. 1986 Ordovician trilobites from north and northeast China. Palaeontogr. Abt. A 192, $157-210$.

Zhou, Z. Y. \& Zhen, Y. Y. 2008 Trilobite-constrained Ordovician biogeography of China with reference to faunal connections with Australia. Proc. Linn. Soc. N $S W$ 129, 183-195.

Zhou, Z. Y. \& Zhou, Z. Q. 2008a Latest Cambrian and Ordovician. In Trilobite records of China (eds Z. Y. Zhou \& Y. Y. Zhen), pp. 208-274. Beijing, China: Science Press.

Zhou, Z. Y. \& Zhou, Z. Q. 2008b A new Ordovician trilobite Ovalocephalus eoprimitivus (sp. nov.) from the Dawan Formation, Yichang, western Hubei. Acta Palaeontol. Sin. 47, 454-456.

Zhou, Z. Y., Zhou, Z. Q. \& Zhang, J. L. 1989 Ordovician trilobite biofacies of North China Platform and its western marginal area. Acta Palaeontol. Sin. 28, 296-313.

Zhou, Z. Y., Chen, X., Wang, Z. H., Wang, Z. Z., Li, J., Geng, L. Y., Fang, Z. J., Qiao, X. D. \& Zhang, T. R. 1992 Ordovician of Tarim. In Biostratigraphy and geological evolution of Tarim (eds Z. Y. Zhou \& P. J. Chen), pp. 62-139. Beijing, China: Science Press.

Zhou, Z. Y., Dean, W. T., Yuan, W. W. \& Zhou, T. R. 1998 Ordovician trilobites from the Dawangou Formation, Kalpin, Xinjiang, north-west China. Palaeontology 41, 693-735.

Zhou, Z. Y., Zhou, Z. Q. \& Yuan, W. W. 1999 Middle Caradoc trilobite biofacies of western Hubei and Hunan, South China. Acta Universitatis Caroline-Geologica 43, 385-388.

Zhou, Z. Y., Zhou, Z. Q., Yuan, W. W. \& Zhou, T. M. 2000 Late Ordovician trilobite biofacies and palaeogeographical development, western Hubei-Hunan. f. Stratigr. 24, 249-263.

Zhou, Z. Y., Zhou, Z. Q. \& Yuan, W. W. 2001 Llanvirn-early Caradoc trilobite biofacies of western Hubei and Hunan. China. Alcheringa 25, 69-86. (doi:10.1080/ 03115510108619214 )

Zhou, Z. Y., Zhou, Z. Q., Siveter, D. J. \& Yuan, W. W. 2003 Latest Llanvirn to early Caradoc trilobite biofacies of the north-western marginal area of the Yangtze Block, China. Special Papers Palaeontol. 70, 281-291. 